\title{
José Daniel Rodrigues da Costa e a imprensa periódica jocosa de Portugal do século XVIII
}

Socorro de Fátima Pacífico Barbosa ${ }^{a}$

\begin{abstract}
Resumo
Este artigo apresenta resultados de pesquisa sobre a imprensa jocosa portuguesa do século XVIII. Tomando como objeto e tema a obra jocosa do escritor português José Daniel Rodrigues da Costa, apresentam-se as peculiaridades deste gênero de escrito, utilizando-se do conceito de "fórmula editorial" de Roger Chartier (1997) e da concepção de D. F. Mckenzie (2004) sobre a determinação do suporte na criação e permanência de novos gêneros literários. Ademais, analisa-se a inclusão do autor no novo regime de profissionalização da atividade literária em Portugal.

Palavras-chave: José Daniel Rodrigues da Costa; Folhetos Jocosos; Imprensa portuguesa do século XVIII.
\end{abstract}


${ }^{1}$ Segundo Inocêncio F. da Silva, "José Daniel Rodrigues da Costa, natural da cidade de Leiria, e nascido a 31 de Outubro de 1757, conforme as informações que tenho por mais verídicas. Contava apenas dois anos de idade, quando foi trazido para Lisboa, e entregue por falecimento de seu pai ao amparo de umas senhoras caridosas, que o educaram e sustentaram, às quais depois valeu agradecido em suas precisões. Não podendo cursar os estudos superiores aos de primeiras letras e gramática latina por falta de recursos pecuniários, acolheuse à proteção do desembargador Antonio Joaquim de Pina Manique, administrador da Alfândega das Sete Casas, o qual lhe conferiu a administração chamada das quatro portas da cidade e ramo de Belém; e como remuneração dos serviços que aí prestara obteve a final uma tença, e a propriedade de um oficio de escrivão e tabelião de notas em Portalegre. Foi Ajudante das ordenanças de Alemquer, e promovido depois a Major da legião nacional do Paço da Rainha. Casou-se quando contava trinta e um anos de idade. Dotado de bom humor, e maneiras afáveis, era bem quisto de todos que o conheciam, e que aplaudiam os seus chistes e ditos naturalmente engraçados, e satíricos. Viveu por muitos anos decentemente dos proventos do seu emprego, e do produto dos muitos papéis que imprimia, e que eram bem acolhidos do público. Sabendo $\mathrm{a} \mathrm{mol} \mathrm{d} \mathrm{a} \mathrm{r} \mathrm{-} \mathrm{s} \mathrm{e} \mathrm{à} \mathrm{s}$ circunstâncias políticas do tempo, escreveu sucessivamente a favor das ideias liberais e

\section{Um autor esquecido pelas histórias da literatura e da imprensa portuguesa}

Um tesouro! É assim que Frazão (2006b), em um dos raros estudos sobre o autor, define a obra de José Daniel Rodrigues da Costa, ${ }^{1}$ que pode ser considerado um daqueles homens de letras que exerceram a função de jornalista e, como tal, escreveu em periódicos, publicou um número razoável de entremezes, cartas, diálogos e poesias, a maioria deles um grande sucesso de público e de vendas, atestado pelo número expressivo de títulos e de edições. José Daniel também testemunhou algumas reedições em vida dos seus folhetos, o que, para seu melhor biógrafo, Inocêncio da Silva, era "cousa não muito ordinária entre nós" (SILVA, 1824, p.185 V. IV, p. 304). Algumas dessas obras também foram reeditadas após a sua morte, ocorrida em 1832. As referências de Inocêncio da Silva sobre a biobibliografia do autor ainda são as únicas originalmente escritas que vêm se reproduzindo nos raros estudos que lhes são dedicados ou que, de forma indireta, abordam parte de sua obra (CARDOSO, 1977; FRAZÃO, 2006b; SANTOS, 1987; PALMA-FERREIRA, 1974). Nem é preciso, portanto, dizer que falta aos quadros da história da imprensa, da literatura e até mesmo do teatro portugueses um estudo de fôlego sobre o autor, pois, a despeito do sucesso do público, seu nome não consta do cânone português, nem do teatro ${ }^{2}$, nem da literatura e tampouco do jornalismo.

Este artigo visa, ao mesmo tempo, dar visibilidade à produção escrita deste autor e chamar a atenção para uma forma de periódico, bastante popular nos fins do século XVIII e início do XIX, que ora é apagada pela historiografia da imprensa, ora é por esta desdenhada e nem mesmo chega a fazer parte da chamada literatura da época. Muito próxima da prática de divulgação de notícias, das relações, das cartas dos séculos anteriores, estes periódicos circulavam em folhetos, in-quarto e in-oitavo, semanalmente ou mensalmente, sendo vendidos por cegos (SANTOS, 1987). Esta abordagem busca restaurar a produção escrita de José Daniel Rodrigues da Costa, tido como "poeta e prosador de segunda categoria" (CARDOSO, 1977). Contudo, procura não incorrer numa abordagem que o tome isoladamente como uma "figura romântica, magnífica e solitária de autor soberano", mas a partir das determinações 
do governo absoluto. O Sr. D. Miguel the concedeu uma pensão anual de três molhos de trigo, que pouco tempo desfrutou, falecendo aos 7 de Outubro de 1832 em casa própria, na travessa do Forno ${ }^{\circ}$ 2, freguesia de N.S. dos Anjos, em cuja igreja paroquial foi sepultado defronte do altar do Santíssimo. Era de maravilhar a ânsia com que nos tempos antigos, pelo testemunho dos que o presenciaram, se procuravam os seus escritos, publicados na maior parte periodicamente, e que (cousa não muito ordinária entre nós) foram reimpressos ainda em sua vida". In: SILVA, 1824, 4, p. 304305.

${ }^{2}$ Incluído na História da Literatura Portuguesa, de Antonio José Saraiva e Oscar Lopes, no item "O teatro em Portugal na época arcádica", onde lhe é dedicado apenas um parágrafo a seguir transcrito $(1979$, p. 666) "Há também no Teatro do Salitre e no da Rua dos Condes entremezes, breves farsas, como as do muito popular autor satírico José Daniel Rodrigues da Costa (1757 - 1832), o Josino Leirense na Nova Arcádia), publicadas em Teatro cômico de pequenas peças, Lisboa, 1797, que inclui 15 farsas e entremezes; $\mathrm{p}$ e $\mathrm{r} \mathrm{s}$ o $\mathrm{n}$ a $\mathrm{g}$ e $\mathrm{n} \mathrm{s}$ significativos: o falso fidalgo, o toureiro decadente, a menina sabichona, o taful, em contraste com tipos populares". Teófilo Braga (1984) sequer o menciona entre os árcades. históricas do tempo, que constrangem o autor que "suporta as múltiplas determinações que organizam o espaço social da produção literária ou que, de modo mais geral, delimitam as categorias e as experiências que constituem as próprias matrizes da escrita" (CHARTIER, 1999, p. 49). Ademais, a recuperação deste autor e de parte de sua obra tem importância para a história da imprensa no Brasil, pois, a julgar pelo número de títulos disponíveis na biblioteca do Real Gabinete Português de Leitura do Rio de Janeiro, pode-se afirmar que seus folhetos também fizeram sucesso entre os brasileiros e que ali circulou, pelo menos sob a forma de livros.

Por isso, retomar os folhetos de José Daniel Rodrigues da Costa significa, sobretudo, reavaliar não apenas o seu caráter jocoso ou a popularidade dos seus escritos, mas o modo como se deu a apropriação de outros gêneros noticiosos - casos; cartas e sonhos; relações; notícias - e também de outros gêneros retórico-poéticos - máximas e dissertações; epigramas, glosas, sonetos, apólogos, enigmas e adivinhações, como os preferidos do autor - pelo suporte do folheto, em um contexto no qual, ao mesmo tempo, os folhetos ganhavam o caráter periódico da imprensa. Para além do seu "valor literário", sua obra interessa aos estudiosos da leitura e da cultura escrita, pois revela de forma incontestável a passagem do mecenato para o "novo regime literário", no qual o autor vendia e vivia do que escrevia.

Da mesma forma, como se verá na análise a seguir, é possível reconstituir a partir da produção material dos seus escritos, dos anúncios e, sobretudo, dos prólogos os modos de escrever e de ler de certa imprensa do fim do século XVIII e início do XIX, supondo, com Mckenzie (2004), que a exigência dos novos leitores e as formas tipográficas enformam os gêneros novos. No caso em estudo, o gênero novo refere-se à imprensa de caráter jocoso que circulou, sobretudo, em folhetos, cuja história ainda precisa ser contada, sendo a produção de José Daniel Rodrigues da Costa apenas uma parte dela. Sempre pensados como suporte literário por excelência, o folheto de cordel raramente é associado ao jornalismo ou à imprensa periódica, mesmo sendo suporte de uma infinidade de gêneros noticiosos e poéticos, todos de larga aceitação popular. Os folhetos, ou os papéis, como também eram chamados ao serem encadernados e publicados em forma de livro, têm sua principal forma de circulação apagada das histórias da literatura e da 
${ }^{3}$ Santos (1987, p. 10) lista uma variedade $\mathrm{d}$ e $\mathrm{tem}$ a $\mathrm{qu}$ e ocuparam este suporte, confundindo gêneros poético-retóricos com os assuntos por eles tratados. "São Folhinhas de Reza, os Entremezes, as Comédias, as Vidas de Santos, as Éclogas, as Sátiras, os Avisos e conselhos, as Lendas Religiosas, as Narrativas Cavalheirescas, os Sermões, os Autos, as Relações sobre o Terremoto, sobre as Festas de Touros, os Casos Prodigiosos, as Relações de Naufrágios, as Loas, os Diálogos entre as Cozinheiras, as Vizinhas, mas também as Relações Históricas, as Notícias Militares, pequenos tratados que podemos designar de 'divulgação cientifica".

${ }^{4} \mathrm{O}$ autor nomeia cada folheto como Parte. A obra possui dois tomos, sendo o primeiro com 88 PARTES, ou 88 folhetos e a segunda com 52 partes ou folhetos. Cada folheto continha 8 páginas que não eram numeradas em sequência para futura encadernação, como era próprio dos periódicos da época, muito embora a obra tenha índice das matérias e autor informe aos seus leitores como proceder para com a encadernação; "segue-se a este último Folheto o Índice, que se prometeu nos antecedentes, o qual se fica aprontando, e por todo o mês de Janeiro se há de dar aos Senhores Assinantes, e por à venda para quem mandar encadernar a Coleção deste primeiro Tomo" (COSTA, 1798, P. 88, p.8). imprensa. Segundo Santos (1987, p. 8), “a produção de Cordel interessou um grande número de casas impressoras", tanto que os cem folhetos por ela estudados têm como origem vinte e quatro oficinas diversas, o que atesta o sucesso editorial desta fórmula que, além do baixo preço, contava com a disposição dos caracteres e das ilustrações. Muitas também são as referências aos livreiros e papelistas que comercializavam este impresso. A este respeito, a obra de José Daniel Rodrigues da Costa, conforme se verá quando da análise de sua "fórmula editorial", afasta-se um pouco desses folhetos, ao mesmo tempo em que lhe incorpora alguns temas ${ }^{3}$, gêneros, tom e estilo. Não se trata evidentemente de investigar sobre "autoria" ou plágio de obras consagradas, como faz Cardoso (1977, p. 14), ao tomar José Daniel Rodrigues da Costa ou como autor de adivinhas "populares", ou plagiador das adivinhas formuladas por autores consagrados como Francisco Lopes, Rafael Bluteau, Madre Maria do Céu, entre outros. O que este artigo propõe são questões que vão além daquelas comuns aos estudos dos folhetos, que se fixam nos pares: popular $x$ erudito; autor $x$ plagiador; leitor culto $x$ leitor inculto.

Seguindo os passos de Chartier (1997), tento articular o texto, o suporte e a leitura, razão pela qual se formulam algumas questões que se dão entre os "espaços legíveis e suas efetuações". Entre elas, a que indaga sobre a passagem dos gêneros tradicionais da retórica e da poética para o suporte folheto: quais os recursos estilísticos utilizados? Que gêneros e temas dos folhetos tradicionais ajudaram a compor os folhetos periódicos? Que elementos das gazetas e mercúrios se incorporaram a esses folhetos?

\section{O leitor, um consumidor}

No primeiro folheto de Almocreve das petas, ao mesmo tempo em que dá início ao seu diálogo com o leitor, o autor já indica ser avesso ao "Homem ocupado dos negócios" ou o "Homem cheio de aflições", pois para o seu "leitor aplicado e curioso" ele oferece a sua obra "para desafogo das horas vagas, em que ambos teremos o nosso recreio, eu em compor, e vós em comprar" (COSTA, 1798, P.I , p. 1). Esta representação do leitor como um consumidor, um comprador dos seus escritos perpassa toda a sua obra e se apresenta como uma tópica retórica que 
confere unidade temática às suas coleções. No Prólogo desse mesmo volume, encontram-se os seguintes versos:

Baldo estando de dinheiro,

Um ofício aprender quis,

Meti-me a carapuceiro;

Tinha um ano de Aprendiz,

E em talhar fui tão arteiro,

Que as carapuças, que fiz,

Vão servindo ao Mundo inteiro,

E ficam, ... que é um beliz.

(COSTA, 1798, P. I, p. 1)

Na verdade, a relação que o autor estabelece com o leitor como mero curioso, comprador de sua mercadoria, desvela outras representações de práticas de leitura do tempo, entre as quais estão a de emprestar os periódicos e a da sua partilha pela leitura oral. Ao fim dos dois tomos do Almocreve, José Daniel ressente-se desse leitor que quer ler sem querer pagar: "Acabou com o último dia do ano, o Primeiro Tomo desta curiosa Coleção, no presente Folheto N. 88; e esteve em termos de não continuar; porque quase todos gostavam muito de a ler de graça", tópica recorrente em seus prólogos e despedidas (COSTA, 1798, P. 88, p. 7). No último, ele reclama em versos:

Não prossegue o Almocreve como d'antes,

Não por falta de petas,

Mas sim porque lhe faltam assinantes:

Se um Leitor a ler obras se propõe,

É preciso animar a quem compõe;

Quer dizer é bonito, e ler de graça,

Basta, que o meu barbeiro o mesmo faça:

Se no ano seguinte houver quem queira,

Meta-me assinaturas na algibeira:

Sem trezentas haver conta não faz,

Não quero trabalhar, fiquem-se em paz.

(COSTA, 1798, P.52, p. 8)

Outra matéria corrente na relação que se estabelece entre o leitor e seus escritos como mercadoria é atestada pelo preço de 30 réis o folheto, preço que o autor julga pertinente e justo a ser cobrado, com o intuito de divertir o leitor, o que leva, juntamente com outros aspectos que serão mais adiante analisados, à hipótese de que o leitor pobre e sem dinheiro não é aquele a quem os folhetos foram destinados. O assunto é introduzido através de uma carta, na qual o seu pretenso leitor, Aprígio Tafes, lhe faz outras críticas além dessas. A suposição 
${ }^{5}$ Observe-se, na primeira parte de uma Silva publicada em dois folhetos, como o autor achincalha os poetas que vivem as custas do erário público: "Ah, que d'El Rei não quero ser Poeta, / Que receio me fira a mordaz seta; / Que prêmios são os que se tiram disto; /Que Poetas felizes se tem visto? / Elevados na mágica negaça, / Que lhes corrompe do juízo a maça, / De loiro, e palma a imarcescível gloria, / E mil padrões ao Templo da Memória / Que o homem mais vil, que buscam todos / Com diversas tensões, diversos modos; / Estes os frutos são, estes os bens, / Mas na algibeira, nada de vinténs: / Muitos há, que servir possam d'exemplo, / Dos que tiveram no Hospital seu templo; / E em galardão da remontada veia, / Não ter certo o jantar, faltar-lhes ceia; / Alego com Camões, Camões divino, / Nobre brasão do Tejo cristalino, / Cuja alta fama, o tempo não consome; / Morrendo de trabalhos, $\mathrm{e}$ de fome: / O portentoso Tasso incomparável, / Reduzido a miséria lamentável, / Viveu num lazareto ferrolhado, / Como se fora orate rematado: / Ser Poeta eu não quero, antes caixeiro / De farto Mercador, gordo Tendeiro, / Estes sim, que tem bolsas recheadas,/Vão às funções nas seges alugadas, / Mostram nos trajes serem abundantes, / Não se queixam de damas inconstantes, / E o Poeta se vai ver as Meninas, / Vem de noite a marrar pelas esquinas; / Se faz outeiro, em que trabalha, e sua, / Quando lhe escuta um bravo, é cá da rua; / É certo que granjeia a eterna fama, / Mas faltalhe o vestido, a côdea, a cama" (continuar-se-á) (COSTA, 1798, P. 66, T. I, p. $5-6)$. de que esse leitor é uma criação parte da investigação que tenho feito ao longo desses anos sobre a escrita epistolar nos periódicos brasileiros, e que leva a acreditar que muitas dessas cartas escritas pelos leitores foram, na verdade, produções dos editores do jornal. Trata-se de mais um artifício retórico da escrita em periódicos da época, entre as quais predomina a dissimulation, que inclui também o anonimato, o pseudônimo e os papéis encontrados ao acaso ou sub-repticiamente enviados ao autor, todas estratégias de construção discursiva (BARBOSA, 2011). Vale a pena observar que o leitor que o critica tem "sapinhos na língua" e sofre com "hemorroidas":

Não pense v.m. Senhor almocreve, que o Povo come as suas petas, assim como v.m. come delas; o Povo não é tão néscio, como v. m. pensa; [...] porém não me posso calar ao levar v. $\mathrm{m}$. 30 réis por cada papelinho destes; se levasse 5 reis, 10 réis, 15 réis, um vintém, 25 vade in pace, ninguém diria nada; mas 30 réis, dinheiro de injúria, há quem tal faça? Quantos, e quantos mandarão os 30 réis, e a v.m. com eles; e outras cousas mais, que eu calo, por ter sapinhos na língua; se eu melhorar das hemorroidas, moléstia que não me deixa sossegar, prometo fazer-lhe uma crítica do tamanho da sua cavalgadura [refere-se ao cavalinho da ilustração do folheto]; e por ora conheça, que sou seu Venerado e Criado Aprigio Tafes. (COSTA, 1798, T. I, P. 39, p. 2)

Ao que segue a resposta do autor. Primeiro, mais uma vez, desqualifica o leitor, que faz fiado, gosta de beber vinho e não demonstra qualquer constrangimento com as críticas. Além disso, insere as suas petas no rol de outras mercadorias, numa clara associação do trabalho intelectual como produto de consumo ${ }^{5}$. Ademais, não deixa de assinalar a sua formação especializada:

Senhor Aprigio Tafes, Recebi a sua crítica Carta, que muito estimei, por ter também aonde meter a foice; ainda que é em seara alheia; mas visto que v. m. supõe Pica-me Pedro \&c: olhe, Sr Aprígio, todos comem palha, se lha sabem dar, e de mais é melhor comer petas, que lagosta com tripa, que faz cólica; [...] fique de aviso não falar mais nisso, senão quer que lhe descosa o fiado. A respeito dos 30 réis, a que v. $\mathrm{m}$. chama dinheiro de injúria, vá ouvindo, quantas cousas tem este preço; trinta réis custa uma couve boa, trinta réis a folhinha de porta, 30 réis um copo de ponche, 30 réis um arrátel de figos, 30 réis a chávena de café bom, 30 réis uma posta de bacalhau com azeite na taberna, 30 réis custava a Gazeta [...] e 30 réis um quartilho de tinto, como v. m. sabe melhor do 
que eu: Pelo que, todos estes trinta réis não injuriam a aljava aonde se recolhem; como se hão de injuriar a minha, que é Almocreve hoje de Petas, e antigamente de Estudantes de Coimbra, onde me doutorei em pulhas, em petas, e em tudo o mais que se dá por este tempo? [...]

Ainda sobre a relação entre o escritor e o leitor, no Folheto 11 de o Barco da carreira de tolos (1803), em resposta a uma carta que recebeu de um seu amigo, na qual the mandava pedir notícias e novidades da Corte, o autor faz uma comparação entre os tempos antigos e modernos; em seguida, aproveita para reclamar da sua sorte como escritor que vive de assinaturas, pois o "gosto de ler tem diminuído uma grande parte, porque os mais homens mudaram de gosto": "os pobres querem ler de graça porque às vezes nem tem um vintém para pão" (COSTA, 1803, p. 20, F. XI). Do seu ponto de vista, a venda de seiscentas coleções para Portugal e as Américas é motivo para choro. O interessante é que ele nomeia o assinante e o leitor de folhetos avulsos de curiosos: "seiscentos curiosos em uma capital destas os devia haver duas freguesias", e continua seus lamentos, sem esconder que a sua vocação jornalística está diretamente relacionada aos lucros que daí possa advir: “Eis-aqui, meu estimável amigo, o que me tira todo o gosto de pegar em pena, porque extrair seiscentas Coleções em uma capital como esta, gastar trezentos mil réis nas despesas da impressão, e esperar que se venda o resto, como os carapaus na Ribeira, é triste cousa" (COSTA, 1803, p.21, F. XI). Pode-se afirmar que esta tópica é recorrente nas obras de José Daniel Rodrigues e se caracteriza como um dos muitos temas que conferem aos seus escritos a unidade textual característica da "fórmula editorial" proposta pelos seus folhetos, sobre a qual tratarei mais adiante.

Um estudo à parte poderia ser consagrado à representação da mulher leitora, não apenas dos periódicos, mas da cultura impressa em geral. A visão da mulher leitora de José Daniel não difere muito daquela de outros autores do tempo, principalmente quando se trata da leitura de romances ou novelas. Na falta dos primeiros quatro folhetos de Barco da carreira dos tolos (1803) e de não haver qualquer menção às senhoras leitoras na despedida do referido título, arrisco informar que a leitora da sua obra foi incluída em um prólogo pela primeira vez em 1805. No prólogo de Hospital do mundo, 
ao invocar leitores e leitoras, ele se explica, em longo parêntese, afirmando dirigir-se a ambos os sexos, para afastar-se do "ranço dos Prólogos", que sempre se dirigem aos homens prática corrente em todos que escreveram até aquele momento - "como se algumas Senhoras não viessem ao Mundo com formosos olhos para lerem, e com juízo para entenderem, e gostarem" (COSTA, 1805, p. 3). Conforme se observa nesta breve passagem, o autor está em sintonia com o seu tempo e também não perde de vista o fato de ter nas mulheres consumidoras dos seus folhetos.

A análise aqui apresentada se faz sempre levando em consideração as duas precauções necessárias apontadas por Chartier (1997, p. 27) em sua abordagem da Bibliotheque Bleue, e que podem ser extensivas aos folhetos de José Daniel Rodrigues da Costa. Conforme o historiador, não se deve considerar esses "textos compilados como 'populares em si', visto que pertencem a todos os gêneros de literatura erudita; considerar que a maior parte teve, em geral, uma primeira existência editorial, por vezes bastante longa, antes de entrar para o repertório dos livros" (CHARTIER, 1997, p. 27).

Outro aspecto a ser considerado é o de chamar a atenção para a circulação da notícia e da literatura em forma de folhetos de regularidade periódica antes da implantação da imprensa no Brasil. No que tange à história da imprensa no Brasil, existe uma abordagem mítica, sempre às voltas com a existência de uma prensa clandestina antes da instauração da Imprensa Régia em 1808. Este é o outro enfoque deste trabalho. Neste artigo, parto do pressuposto de que "o surgimento da imprensa periódica no Brasil não se deu numa perspectiva de vazio cultural, mas em meio a uma densa trama de relações e formas de transmissão já existentes, na qual a imprensa se inseriu" (MOREL, 2009, p. 163).

Uma dessas formas de transmissão foi a carta que, publicada ou não, alimentou as gazetas manuscritas e os periódicos impressos que circularam tanto na corte quanto na América portuguesa. Desta forma, tenta-se sair da perspectiva teleológica, também presente na história da imprensa portuguesa, como bem observou André Belo (2004, p. 16), segundo o qual "a investigação sobre as publicações periódicas portuguesas nos séculos XVII e XVIII foi marcada, durante muito tempo, pela busca de um momento inicial - o 
primeiro jornal português - e por uma perspectiva finalista ou teleológica". Assim, se, por um lado, esta perspectiva lia mercúrios e gazetas manuscritas como embriões "do que haveria de se formar depois, ou um mero ponto de passagem em direção ao gênero jornalístico moderno, cujo modelo foi situado na segunda metade do século XIX"' (BELO, 2009, p. 17), por outro, desconsiderou a sua forma periódica, impressa em folhetos, cujo preço e assuntos tinham destinação contrária àquela da Gazeta de Lisboa, ou de qualquer outro periódico político, por exemplo.

Com efeito, desde Alfredo da Cunha (1941, p. 66), percebese certo menosprezo por esta produção escrita, como pode ser observado na passagem a seguir: "Nem ainda, de 1701 a 1800, o jornalismo chegou a exercer preponderância apreciável. As duas dúzias de jornais que se conhecem do século XVIII pesaram escassamente, em relação a tão longo período, na balança das letras pátrias". Ao citar Adrien Balbi, o autor endossa o pressuposto de que "era com razão que, havia alguns anos, se censurava aos Portugueses que a falta de periódicos abrisse considerável vácuo na sua literatura".

Embora incluídos por Tengarrinha (1982, p. 54), nos primórdios da imprensa portuguesa, como "periódicos humorísticos e de diversão pura", sua importância se resume a testemunhar 'como documentos da maior importância para o conhecimento' a crítica social e a libertação do espírito crítico da época sobre a sociedade. Assim, Tengarrinha, ao traçar as características gerais do que considerou primórdios da imprensa portuguesa, revela a mesma face teleológica observada por Belo (2004), no que concerne às gazetas manuscritas: são objetos imperfeitos, faltosos, cujas "limitações impostas aos jornais transformavam-nos em instrumentos dóceis dos poderes políticos e religiosos ou em meros meios de diversão, normalmente frívolos" (TENGARRINHA, 1982, p. 116).

Pode-se observar nesses folhetos de José Daniel Rodrigues da Costa, que classifico como noticiosos e recreativos, funções desde sempre associadas à circulação dos chamados folhetos de cordel, "essa fórmula editorial menor" (SANTOS, 1987, p. 7) na tradição cultural portuguesa que, conforme se verá, será motivo de chacota daqueles que faziam a literatura erudita. Segundo Santos (1987, p. 8), "a produção de Cordel interessou um grande número de casas impressoras", tanto que os cem folhetos por ela 
estudados têm como origem vinte e quatro oficinas diversas, o que corrobora o sucesso editorial desta fórmula, além do baixo preço, da disposição dos caracteres e das ilustrações.

A esses folhetos também é possível aplicar aquilo que Chartier identificou no cordel francês como sendo "fórmula editorial". Por fórmula editorial, entende-se com Roger Chartier (1988, p. 178), aquilo "que dá ao objeto formas próprias, que organiza os textos de acordo com dispositivos tipográficos específicos", cujo repertório é "aquilo que é contemporâneo do leitor, do seu horizonte de expectativa, não é o texto mais ou menos antigo, mas a forma impressa na qual ele é dado a ler". No caso dos folhetos de José Daniel, esta fórmula, ao contrário dos folhetos franceses, sempre forjada pelos editores, foi construída pelo próprio autor, como revelam várias passagens dos seus escritos.

Estas passagens também servem para refletir sobre este modo de circulação e de produção da imprensa periódica portuguesa. Sobre a produção periódica do autor, especificamente, Palma-Ferreira (1974, p. 23) afirma que, "com efeito, mau grado o seu caráter muito particular, não é de outro modo que devemos considerar essas publicações". Para o estudioso, "são autênticos jornais, ao gosto do século XVIII tardio, mesclando o entretenimento com a sátira e, até, com verdadeiras demonstrações de humor, tão raro na tradição portuguesa anterior à segunda metade do século XIX".

Palma-Ferreira (1974) refere-se a um tipo de periódico que se consolidou na metade do século XVIII, cuja característica era ser publicado em folhetos, com o propósito ao mesmo tempo de ensinar e divertir, como o Oculto instruído que para lícito divertimento e honesta recreação se á de publicar dividido em diferentes partes (1756); Palestra admirável (1759) (IMPRENSA PERIÓDICA, 1941). Tengarrinha (1982, p. 54) apresenta outro nome e data para este periódico: Palestras críticas e semijocosas em que se repreendem os costumes e modas afetadas (1771). O apogeu desses periódicos foi, sem dúvida, o século XIX, quando, no caso de Portugal, apresenta inúmeros títulos, entre os quais os de José Daniel Rodrigues da Costa: Variedades. Publicação literária, compreendendo história geral, anedotas (1802); Tardes divertidas ou conversações curiosas sobre a história natural, sacra, civil e fabulosa (1804); Anacleto de recreação e erudição (1805); Divertimento instrutivo ou coleção escolhida de novelas, histórias, contos (1805); 
Coleção de mentiras e verdades (1806); (IMPRENSA PERIÓDICA, 1941). Tengarrinha (1982, p. 55) também inclui neste rol O piolho viajante (1803), um caso célebre de apagamento do gênero e do suporte, depois de sua publicação como exemplar encadernado, quando é frequentemente apropriado como romance, pelo menos no Brasil.

\section{Um autor português no novo regime literário: a profissionalização da atividade literária}

Como era comum à época, José Daniel testemunhou em prólogos, introduções, cartas, crônicas e poesias o ofício do escritor de folhetos como aquele que escreve "para todas as classes", sempre em oposição àqueles que escreviam para um público mínimo. Este tópos recobrirá toda a obra do autor, tornando-se, portanto, um dos focos deste estudo, posto que, ao fazê-lo, revelam-se as representações correntes sobre as práticas de escrita e de leitura da época, principalmente de um gênero jornalístico considerado menor (TENGARRINHA, 1982), escrito por um autor menosprezado (CARDOSO, 1977).

Desprezado pelos contemporâneos, produtores da chamada alta literatura, o autor representa esta relação usando a ironia. Observa-se em muitos desses escritos como, já em fins do XVIII e início do XIX, dava-se o embate entre as obras de ampla aceitação comercial, e aquelas escritas para um público diminuto, pelos chamados autores sérios, a quem José Daniel da Costa nomeou de "uns mestres de retórica de açougue" (COSTA, 1803, p. 30, F.XII):

Ora pois, eu não sou daqueles ambiciosos, que fazem raras as suas produções, dificultando-as muito: não, Senhores, sou muito mais liberal do que isso, e já passei ordem na loja da Gazeta para se dar esta Obra a toda a gente que a for comprar. Lembrei-me primeiramente de a dar de graça; mas por nos não pormos em cumprimentos, porque muitos de Vv.Mm. se haviam de lesar em mandar-me alguns presentes para desonerarem a minha generosidade, assentei, por lhes salva estes incômodos, que era melhor estabelecer-lhe o preço de oito tostões a assinatura, e em Folhetos avulsos sete vinténs por cada um (COSTA, 1805, p. 4, F. I)

Membro da Nova Arcádia ou Academia de Belas Letras, conhecido pelo pseudônimo de Josino Leirense, José Daniel Rodrigues da Costa parece carregar consigo e nos seus escritos 
as contradições que informam a função e o papel do novo "sistema literário, baseado na imprensa e centrado no autor", identificado por Alvin Kernan (1987, apud CHARTIER, 1997, p. 62), no autor inglês, Samuel Johnson, com a antiga prática de vender folhetos de mão em mão, ou com a ajuda dos cegos.

A relação de patronato de José Daniel com o irmão do intendente Pina Manique, o desembargador Antonio Joaquim de Pina Manique, "rendeu-lhe uma tença, e a propriedade de um oficio de escrivão e tabelião de notas em Portalegre. Foi Ajudante das ordenanças de Alemquer, e promovido depois a Major da legião nacional do Paço da Rainha", simultaneamente à época em que, como afirma Inocêncio, "vivia do produto dos muitos papéis que imprimia, e que eram bem acolhidos do público" (INOCÊNCIO, 1824, p.304, v. IV).

Não cabe nos limites deste trabalho discutir o valor, o quanto ganhava, o quanto lucravam autor e editor - neste caso, o autor em várias passagens se autodenominava editor; quais as livrarias e casas que vendiam os seus folhetos; bem como o fato de vendê-los no início da carreira como ambulante e já nos últimos títulos anunciá-los com venda em sua própria casa e na loja da Gazeta [de Lisboa]. Esses artefatos também demonstram como a sua "obra" também era vendida em muitas casas especializadas de vários pontos do país. Só a título de ilustração, observa-se em anúncios das últimas páginas do folheto Hospital do mundo, de 1805, uma inversão daqueles que saem regularmente nos jornais da época. Nele, não está escrito "na loja de fulano", ou na loja da Gazeta, como era usual, numa clara demonstração de que a obra do autor estava subjugada a seu editor; o folheto já inicia com o nome José Daniel Rodrigues da Costa tem à venda todas as suas Obras na loja da Gazeta, e em sua casa na rua direita dos Anjos esquina da Travessa do Forno, $N$. 1, pelo preços seguintes. Ao que segue a lista de todos os folhetos e outros títulos com os preços e um debochado aviso no qual informa aos leitores terem acabado todas as "impressões de suas rimas", que seriam, em breve, reimpressas com o acréscimo de poesias divertidas (COSTA, 1805, p. 32).

Essa história, contudo, mesmo que trate de autor canônico, revestido de valor estético, pode revelar dados importantes sobre o início da profissionalização dos escritores em Portugal. Há que se observar também que a permanência 
${ }^{6}$ Em 1871, é publicado o Novo almocreve das petas: livro alegre e folgazão no gosto do antigo "almocreve das petas", do célebre José Daniel Rodrigues da Costa. Lisboa: Tipografia Universal. Sua capa aponta para novas relações, das quais Joaquim José Bordalo \& Luiz de Araujo são os proprietários editores do título, sendo o último o redator. O livro era vendido na casa do proprietário editor. Segundo Luis de Araujo, o seu redator, a publicação do livro em folhetos tinha dois fins: "o de fazer renascer o género típico e português do Almocreve de Petas do célebre Josino Leirense, José Daniel Rodrigues da Costa: segundo, apontar ridículos gerais satirizá-los, trabalhar carapuças para o vulgo, fazer graça sem ofender e proporcionar uma leitura jovial a todos que nos lerem, especialmente para o nosso bom povo que tão crivado anda de desgostos e de ... impostos" (ARAÚJO, 1879, p. 3). Em 1879, Luiz de Araujo publicará uma segunda edição de Novo almocreve de petas, na capa do folheto, e seu nome constará como o do autor, sem qualquer menção a José Daniel, cuja autoria será mencionada apenas na folha de rosto. (ARAÚJO, 1879). e a apropriação desses escritos por outros autores, em várias edições após a morte do autor, até finais do século XIX6 já são matéria de interesse para a história da leitura e dos folhetos. Agindo como homem do seu tempo, José Daniel se recusa a aceitar a prática corrente da imprensa periódica da época, a de esconder-se sob o anonimato e a dissimulatio (BARBOSA, 2011), bem como o recurso à "ficção do manuscrito" e a construção do autor apócrifo - todas as estratégias utilizadas pelos autores que se sentiam desconfortáveis com o "recurso inevitável à imprensa" e promoviam o que Chartier chama de "retraimento do autor" (1997, p. 63). De fato, em Câmara ótica (1807, p. 4, F. I), o autor dirá a respeito de vários folhetos que passaram a circular tentando representar o seu estilo: "e para uma vez dissipar esta preocupação fique o benigno Público desde já na certeza de que obra, que não leve o meu nome, não é minha. Nunca me agitei a entrar no rol dos Anônimos, porque se a obra saiu feliz, não desar ter o nome do Autor, e se saiu informe, tenho valor, e ânimo para sofrer a sangue frio a crítica merecida".

Noronha (1867, p. V. 3), por sua vez, ao narrar a relação pouco amistosa entre o autor e Bocage, que o chamava pejorativamente de Beleguim do Parnaso, testemunha que "José Daniel [tinha] por uso andar com as algibeiras pejadas de seus folhetos, oferecendo-os pelas ruas a quantas pessoas topava". Essa é uma das muitas representações do autor que vão de encontro a uma história da literatura e da imprensa, que abstrai dos seus estudos a relação material e econômica que carregam os textos literários e jornalísticos. Escrevendo e fazendo sucesso entre o fim do século XVIII e início do XIX, o autor é exemplo acabado daquilo que Chartier chama de "ligação um tanto paradoxal entre profissionalização da atividade literária" e a "autorrepresentação dos autores numa de ideologia do gênio próprio, baseada na autonomia radical da obra de arte e no desinteresse do gesto criador" (1997, p. 61).

José Daniel Rodrigues da Costa soube como talvez nenhum outro tirar partido desta nova configuração do "regime literário" (CHARTIER, 1997, p. 64), dando visibilidade ao seu nome, sempre o associando às suas obras de sucesso, e dela tirando lucros que, em sua opinião, eram justos e legítimos, como se pode verificar nas passagens a seguir, em resposta a 
uma das muitas críticas que recebe através de cartas de um leitor de Évora:

Meu Amigo, trabalhe a inveja como quiser, que lhe não posso chamar outra cousa: hei de escrever, hei de compor, e hei de lucrar, uma vez que o Céu me pôs nesta ordem de vida para minha subsistência: não devo desprezar, nem pôr em inação esta pouca habilidade, que foi servido conferir-me; e quem não faz isto, faz outras cousas impróprias da honra dos homens, e prejudiciais ao Públio [sic] (COSTA, 1802, p. 18, F. 6, grifos meus)

Partilho com Chartier (1997) e Santos (1987) a opinião segundo a qual, os folhetos, ao contrário da suposição que os identificava com o público e à cultura popular, tinham uma destinação ampla, que podia envolver várias classes de leitores. Esta destinação a todas as classes é tema frequente de prólogos e cartas, em que o autor explícita ou implicitamente rebate as críticas dos que lhe cobram compromisso com o saber ou a "iluminação do século presente".

Em vários dos prólogos de sua obra, José Daniel Rodrigues da Costa demonstra ser a publicação e o surgimento dos seus folhetos uma demanda dos seus leitores, o que certamente o levou a apropriar-se dos gêneros e temas de sucesso. No

${ }^{7}$ Esta obra se compõe de 12 folhetos, cada uma dedicada a uma classe de tolo, descritos em sequência: folheto dos tolos modistas; dos namorados; dos mal casados; dos mal criados; dos velhacos encobertos; dos bêbados; dos soberbos; dos presumidos; dos queixosos da fortuna; dos crédulos; dos que em tudo se metem; e, por último, dos tolos em geral.

${ }^{8}$ Trata-se de um escrito compiladojunto a outros de vários gêneros, em uma encadernação com o título de Papéis vários, com o índice em manuscrito. A julgar pela data dos outros impressos - 1806 e 1809 em sua maioria -, essa crítica é posterior a 1805, data da publicação de Hospital do mundo, obra referida de forma explícita no libelo. prólogo de Hospital do mundo, obra crítica, moral, e divertida, em que é médico o desengano, e enfermeiro o tempo, publicado em 1805, o autor explica que, a despeito de ter publicado toda a sua obra - Almocreve de petas, Comboio de mentiras, Espreitador do mundo novo e o Barco da carreira dos tolos ${ }^{7}$ - , "ainda há muito mais que dizer, sem me encontrar com o que já disse; e fica-me disso uma satisfação [...] devendo parte deste prazer aos meus honrados assinantes, que tanto me tem animado com o louvor e a Assinatura" (COSTA, 1805, p. 3, F. I), numa clara relação que associa sua produção à demanda dos leitores.

Essas críticas não parecem contemporâneas ao ano de 1807, quando é publicado o texto acima, pois em um folheto anônimo, com data presumida ${ }^{8}$ de 1800 , publicado em Lisboa, cujo título é Crítica às obras de José Daniel, no que parece ser uma conversa por meio de cartas, o autor, respondendo à Frioleira (parvoíce, tolice), lamenta a sua enfermidade nesse "hórrido Hospital", ao passo que não lamenta sua morte, uma vez que terá "gosto de ver esse grande enterro iluminadíssimo com as luzes das vossas escritas" (CRÍTICA..., 1800, p. 3). O 
${ }^{9}$ Segundo Noronha (1867, p. 5), citando testemunho de Couto, Bocage ficava bastante incomodado quando os cegos apregoavam as obras de José Daniel, "lembrando do tradutor das Geórgicas, e escandalizado do homônimo voltava-se para o cego e dizialhe: - O bruto, ou tiralhe Daniel ou põe-lhe Rodrigues! Mas quem será este Daniel? Será Leonel?".

${ }^{10}$ No folheto 6 de $O$ espreitador do mundo novo (1802, p. 19), o autor em resposta à reclamação de um leitor sobre o valor de sua produção assim lhe responde: "se dá por mal empregado o dinheiro, que tem gastado nas minhas obras, alugue uma cavalgadura, venha a Lisboa, e debaixo da Arcada do Terreiro do Paço há cegos, que ainda lhe hão de dar alguma coisa por elas". mais interessante deste papel, que critica a obra do autor de Almocreve de petas, é o fato de associar a produção de José Daniel aos antigos folhetos vendidos pelos cegos, o que não deixa de ser verdade:

Deveis saber, que não pretendo me deixeis no vosso testamento a imortal fama, que vos pertence de deixar muitos cegos ricos, os quais antes de eu nascer publicavam com tão alta voz os títulos das vossas obras, que me dizem pessoas antigas, que viram até João Burro perder a venda de imensos copinhos de aguardente, pela trapalhada, que os mesmos cegos faziam por todas as esquinas das ruas nesta Capital (CRÍTICA..., 1800, p. 3).

Trata-se de inegável testemunho de uma época ${ }^{9}$, na qual se observam antigas e novas maneiras de circulação de impressos, sendo que, do ponto de vista de quem critica ponto de vista endossado pelos historiadores da literatura e da imprensa portuguesas -, a filiação da venda dos escritos a uma tradição na qual papéis e folhetos circulavam comercializados pelos cegos ${ }^{10}$, transforma este gênero de impresso em objeto escrito de menor valor.

Voltando à Crítica à obra de José Daniel, especificamente à lira "A águia falando com o papagaio", também se observam severas críticas ao estilo do autor que reproduzem, em certa medida, suas palavras no prólogo de Câmara ótica. Nele, José Daniel comenta o fato de ser acusado de falar demais e de se repetir, daí o epíteto de Papagaio, compatível com os "escritores do parlamento baixo" (COSTA, 1807, p. 5, F. I), em oposição à Águia, que seria representante dos escritores dignos de figurar no panteão da glória literária, aqueles que não vendem folhetos como os dos cegos e que tampouco cometem faltas "contra a Literatura e a Poética" (CRÍTICA À OBRA DE JOSÉ DANIEL, 1800, p. 3).

De asa curta és Papagaio

Rasteiramente Pulando,

E ao ramo de indignas petas

Tonto fostes repousando.

Muita inveja te causavam

As belas Águias cantando,

Quais no terno som da Música

Aos astros iam voando. 
Agradou-te o baixo assunto

Desses pobres almocreves,

Onde as cargas de patranhas

Impor às Letras te atreves.

(CRÍTICA À OBRA DE JOSÉ DANIEL, 1800, p. 7)

Algumas dessas críticas eram feitas pessoalmente, em plena luz do dia, como aqueles ultrajes proferidos por Bocage, outros, entretanto, vinham em forma de sonetos. É possível perceber no exemplo abaixo (um de muitos) que Noronha (1867) o acusa de ter escrito contra o autor do Almocreve, utilizando os mesmos argumentos para rebaixar a obra de José Daniel, sendo o principal deles o fato de vender "as rimas pela rua", numa clara oposição àqueles que não o fazem, como era o caso do próprio Bocage:

Das petas o almocreve é cousa tua,

Bem se vê, Daniel, na frase e gosto:

Adiça três de Abril, ou seis de Agosto,

É de quem vende as rimas pela rua

Cheira, a teu nome o roubo da perua,

E entre o tostado arroz o gato posto;

Eis a obra melhor que tens composto,

Inda que de artifício e graças nua.

A gente por Lisboa anda pasmada

Vendo-te farto, e cheio como um ovo,

Dos alvos pintos que te deu por nada;

E o frio terror sussurra o povo,

Que a tua estupidez anda pejada,

E que cedo se espera um parto novo.

(BOCAGE, In NORONHA, 1867, p. 2)

Vê-se nessa citação que José Daniel não só encontrou a fórmula para o sucesso editorial (que alcançaria definitivamente no século XIX), como também o tom correto para não protelar ou proibir a sua publicação pela Mesa do Desembargo do Paço, vigilante com relação a este gênero de escrito. Contudo, observase em $O$ Almocreve de petas, bem como nas outras obras jocosas do autor, o mesmo caráter moralizante e pedagógico implícito nas sátiras dos folhetos que Santos (1987, p. 16) analisou. Para a autora, este aspecto é resultado da ação da censura estabelecida à época, "há sempre um fim moral, uma proposta de conduta que não põe em causa os valores estabelecidos". No caso desse 
11 Só estão listadas as primeiras edições, que foram todas consultadas na Biblioteca Nacional de Portugal. Almocreve de petas ou moral disfarçada para correção das miudezas da vida. Lisboa: Oficina de Simão Thaddeu Ferreira, 1798 e 1799 ; Comboio de mentiras, vindo do reino Petista, com a fragata Verdade encoberta por capitania. Lisboa: Oficina de Simão Thaddeu Ferreira, 1801; O Espreitador do mundo novo. Obra crítica, moral e divertida. Lisboa: Oficina de Simão Thaddeu Ferreira, 1802; Barco da carreira dos tolos. Obra crítica, moral e divertida. Lisboa: Oficina deSimão Thaddeu Ferreira, 1803; O Hospital do mundo. Obra crítica, moral e divertida, em que é médico o Desengano, e enfermeiro o Tempo. Lisboa: Oficina de Simão Thaddeu Ferreira, 1805; Câmara óptica, onde as vistas às avessas mostram o mundo às direitas. Lisboa: Oficina de Simão Thaddeu Ferreira. 1807/1811; Tribunal da Razão, onde é arguido o dinheiro pelos queixosos da sua falta. Obra crítica, alegre e moral. Lisboa: Impr. da viúva Neves e Filhos, 1814; Revista dos gênios de ambos os sexos. Lisboa: Impressão Régia, 1815; Roda da Fortuna, onde gira toda a qualidade de gente, bem ou mal segura. Obra crítica, moral e muito divertida. Lisboa: Impressão Régia, 1816/1817; Os enjeitados da Fortuna expostos na roda do tempo. Obra moral e muito divertida. Lisboa: Impressão Régia: 1817/1818. escritor, trata-se de um projeto pessoal, defendido em quase todos os seus títulos. Em Hospital do mundo, ele reitera o seu papel de não faltar aos termos decentes e que "a crítica, a jovialidade, e a moral têm sido a base deste gênero de obra", fato reiterado em praticamente todos os subtítulos de suas coleções, como se observa a seguir. É a mesma "moral" que condena o gênero que irá colocar um fim ao sucesso da leitura de folhetos jocosos. Trata-se da leitura dos romances ou, como afirma o autor, da "nova praga de novelas, que se tem publicado: produções estas, que são uma ruína total da mocidade" (COSTA, 1805, p. 5, F. I).

\section{Características do sucesso da fórmula editorial do autor}

Passo a discutir os elementos que fazem da sua obra uma "fórmula editorial" de sucesso. Além da unidade textual, a partir da qual seria produzida uma série, observa-se uma identidade do seu gênero, "quer pela unidade do campo de práticas em que são utilizáveis (exercícios de devoção, recolhas de receitas, livros de aprendizagem, etc), quer ainda pela temática reencontrada em formas diferentes (literatura de vagabundagem, discursos sobre as mulheres, paródias de gêneros e das linguagens)" (CHARTIER, 1988, p. 174). Juntese a isto o que o autor francês chama de "rede de textos", que consiste em fazer com que um estabeleça diretamente vínculo com outro, na medida em que trabalha os mesmos motivos e as relações que, via de regra, não são diferentes entre os seus fragmentos. Uma análise mais aprofundada destes folhetos vai revelar que alguns assuntos se repetem, principalmente aqueles ligados ao comportamento feminino (SANTOS, 1987).

Pode-se afirmar que a fórmula editorial empregada por José Daniel Rodrigues da Costa, na maior parte dos seus títulos, caracteriza-se pela regularidade material, temporal e temática, podendo todos os títulos listados ${ }^{11}$ ser incluídos em tal perfil. Numas das muitas falsas despedidas do autor, ele reconhece que um dos motivos para deixar de escrever os folhetos é "a sua dificuldade em ter falado de iguais assuntos por espaço de seis anos" (COSTA, 1803, p. 31, F. XII).

Passo a enumerar algumas regularidades materiais, presentes em praticamente todos os títulos das coleções, sendo a primeira delas o formato in-oitavo, mantido em todos os folhetos, desde o Almocreve de petas, e que eram depois vendidos 
${ }^{12}$ A primeira edição de Os enjeitados da fortuna (1817), impressa na Tipografia Régia, não contém ilustração, mas a segunda edição (1826), da Impressão de João Nunes Esteves, repete o esquema da ilustração e de uma oitava agora inteiramente relacionada ao título do periódico.

13 Trata-se de obra retirada dos Poemas Lusitanos, António Ferreira. A informação sobre a autoria da estrofe foi encontrada em pesquisa feita no Google, onde se encontra citada em MARINHO, Maria de Fátima. Encomium. In: Península. Revista de Estudos Ibéricos, $\mathrm{n}^{\circ} 0$ 2003: 9-12. Disponível em: http://ler.letras. u p.pt/upload s / ficheiros/artigo12541. pdf separadamente, encadernados ou em brochuras. A regularidade - mensal, quinzenal e semanal - e o fato de levar todos os projetos a cabo sempre foram motivo de orgulho para o escritor, manifestado em vários prólogos e agradecimento aos leitores.

Os títulos, por sua vez, apresentam a mesma semelhança ao sugerir objetos e pessoas associados a comportamentos. Em geral, carregam o sentido alegórico já mencionado, principalmente Hospital do mundo, cujo título pretende abarcar os vícios que não foram debelados em todas as outras obras do autor: "talvez haja quem repare, que tendo eu composto, e falado por espaço de seis anos, a fim de curar o Mundo achacado, ele se ache cada vez mais enfermo" (COSTA, 1805, p. 6, F. I). Visando corrigir os males do mundo a partir das suas causas internas, aplicando-lhe, pois, remédios que só tinham efeitos paliativos, o autor resolve "palear as enfermidades da mesma forma que os Médicos fazem com as moléstias crônicas", cujo caráter alegórico explicita nas palavras do prólogo da obra, que "contém um Hospital do Mundo, onde entram os enfermos com as moléstias, a que tem dado causa os seus mesmos vícios. Achei que o Desengano (que cura tudo) era o melhor Médico para esta Enfermaria; e que de Enfermeiro devia servir o tempo" (COSTA, 1805, p. 7, F. I). A partir de $O$ espectador do mundo novo (1801), o autor irá anexar aos títulos, com imperceptíveis variações, a explicação que também será responsável pela unidade temática de sua fórmula editorial: "Obra crítica, moral e muito divertida".

Outro aspecto que conferirá unidade aos seus folhetos são as ilustrações, presentes desde Almocreve de petas (1798). Em basicamente todos os folhetos, encontra-se no primeiro número uma gravura que traduz seus títulos. A ilustração e uma epígrafe caracterizarão suas obras desde o primeiro folheto ao último ${ }^{12}$. Contudo, estes elementos vão mudando e essa mudança revela gradativamente, na composição dos seus folhetos, o afastamento do autor do círculo da literatura erudita em direção às formas populares. Em Almocreve de petas (1798), ele ainda faz referência ao fato de ser membro da Nova Arcádia ou Academia de Belas Letras. Abaixo do seu nome, informa ser "entre os pastores do Tejo Josino Leiriense". A epígrafe - De areia, cal, e pedra os que edificam/ Baixas, mas necessárias miudezas/As Torres erguem, que tão altas ficam" - é uma estrofe da "Carta Ao Cardeal Infante D. Anrique, regente", de Antonio Ferreira ${ }^{13}$. Em Comboio de mentiras (1801), 
a epígrafe supostamente anônima, de um manuscrito, já é uma alusão direta ao perfil da sua obra: "Geme o prelo com Obras d'alta estima, / Guindadas produções da prosa, e rima: / Eu podia também meter em provas / Um bom recheio de palavras novas: / Mas porque tudo entenda, o que relato, / Falo como meu Pai, que é mais barato." (COSTA, 1801, p. 2).

Retomando o conceito de fórmula editorial de Chartier (1988, p. 178), como sendo o "que dá ao objeto formas próprias, que organiza os textos de acordo com dispositivos tipográficos específicos", cujo repertório é "aquilo que é contemporâneo do leitor, do seu horizonte de expectativa, não é o texto mais ou menos antigo, mas a forma impressa na qual ele é dado a ler", pode-se afirmar que José Daniel executará com muito sucesso essa fórmula. À unidade material já destacada, juntase uma unidade temática, favorecida pelo estilo jocoso, que se caracteriza, segundo o Dicionário da Lingua Portuguesa, de Morais Silva, como aquilo que faz rir: "assunto cômico, e ridículo, cantado, porém ao modo das composições sérias" (1813). A forma jocosa não ri e castiga apenas o comportamento que está contra a moral, mas ri até mesmo do suporte que o sustenta. Este é o caso dos anúncios, tão comuns nos periódicos e jornais diários que, na obra do autor, ganharão caráter risível nas duas primeiras obras - Almocreve de petas e Comboio de mentiras - desaparecendo das obras seguintes, quando o autor passa a anunciar a venda dos seus folhetos, como era usual aos periódicos da época. Um confronto com os periódicos diários e as gazetas poderia extrair sentido dessas notícias, que também parecem se filiar à tradição das antigas relações, que consistiam "na narração de sucessos", segundo o Dicionário, de Bluteau. Em linhas gerais, observa-se linguagem de duplo sentido, motivação dos nomes, anúncios que ridicularizam a moda, como demonstram os exemplos abaixo, notadamente aquele que faz paródia dos costumeiros avisos de livros:

AVISOS.

Há sua falta nesta terra de ovos moles; quem tiver galinhas, que ponham, e as quiser alugar, dar-se-lhe-ão as rapaduras do tacho.

Estabeleceu-se em Valada uma fábrica de velas de sebo sem pavio, que duram o dobrado que as outras. (COSTA, 1797, F. III, p. 7) 
O autor utiliza o formato do folheto para compor em um só exemplar uma obra que trazia, em linguagem vulgar, alguns dos gêneros de sucesso que circulavam em folhetos, em forma isolada, entre eles a carta, a relação, os sucessos e as notícias. Entre as obras de caráter jocoso, chamados de divertimento, estão o estremez - gênero ao qual José Daniel também se dedicou com sucesso - a palestra jocosa, os jogos, as charadas e as adivinhações (CARDOSO, 1977). O conjunto da obra apresenta, com poucas variações, os mesmos gêneros desde o primeiro ao último título publicado: são as poesias em suas formas tradicionais, mas com características jocosas, entre as quais predominam a máxima, a glosa, o mote glosado, o soneto, a epístola - que, aos poucos, ganhará a predominância em prosa - e a anedota.

Concluindo, pode-se afirmar que José Daniel Rodrigues da Costa soube, como nenhum outro autor português do século XVIII, exercer também a função de publicista da sua obra, sempre anunciada na última página do folheto, preparando os assinantes e leitores para as futuras edições, bem como dando acesso aos números perdidos. Um dos exemplos mais visíveis, no que concerne ao uso da alegoria, diz respeito à localização geográfica das notícias. Se em Almocreve de petas observamos que, em sua maioria, essas referências são provenientes de lugares reais - muito embora as notícias sejam brincadeiras - em Comboio de mentiras, os lugares estão diretamente relacionados à matéria em pauta. Por exemplo: "Vale de carapuças" (COSTA, 1802, F. 5, p. 1), para o Reino onde as mulheres seguem a moda de vestir-se com roupas coloridas; "Fofice", (COSTA, 1801, F. 21, p. 1), que trata de um homem enfatuado; "Zeriquitá de Val de Tombos", um peralta, secretário de todas as modas (COSTA, 1801, F. 24, p. 4). Em linhas gerais, estes foram os temas principais abordados pelo autor, entre os quais destaco a sátira, já que o motivo principal foi sempre o fait-divers, os costumes, as modas, além dos próprios escritos jornalísticos, comumente satirizados. Os folhetos de José Daniel Rodrigues da Costa ainda precisam ser estudados a partir de uma ótica que os tome enquanto parte da imprensa periódica portuguesa. Como aquela que inaugura e consolida a instância do leitor, inclusive na sua materialidade. 


\section{REFERÊNCIAS}

ARAUJO, L. Novo almocreve das petas livro folgazão no gosto do antigo Almocreve de petas. $2^{\mathrm{a}}$ Ed. Lisboa: Joaquim José Bordalo, 1879.

BARBOSA, Socorro de F. P. A escrita epistolar como prosa de ficção: as cartas do jornalista Miguel Lopes do Sacramento Gama. Desenredo. Revista do Programa de Pós-graduação em Letras da Universidade de Passo Fundo, v. 7, n.2, p. 331-344, jul./dez. 2011.

BELO, A. "Notícias impressas e manuscritas em Portugal no século XVIII: horizontes de leitura da Gazeta de Lisboa". In: Horizontes Antropológicos, Porto Alegre, ano 10, n. 22, p. 15-35, jul./dez. 2004.

BRAGA, T. História da literatura portuguesa. Os árcades. Lisboa: Imprensa Nacional; Casa da Moeda, 1984. $4^{\circ} \mathrm{V}$.

CARDOSO, C. L. “José Daniel Rodrigues da Costa, presumível autor de adivinhas tidas por 'populares'? (uma pesquisa em curso)". In: Separata do Boletim cultural da assembleia distrital de Lisboa. III Série - No LXXXIII, 1977. p. 3 - 38.

CHARTIER, R. A ordem dos livros. Lisboa: Vega, 1997.

(Dir.). As utilizações do objecto impresso. Algés: Difel, 1988.

COSTA, J. D. R. da. Hospital do mundo, obra crítica, moral e divertida, em que é médico o desengano, e enfermeiro o tempo. Lisboa: Oficina de Simão Thaddeu Ferreira, 1805.

. O espreitador do mundo novo. Lisboa: Oficina de Simão Thadeu Ferreira, 1802.

. O almocreve de petas, ou moral disfarçada para correção das miudezas da vida. Of. de Simão Tadeu Ferreira ( $2^{\mathrm{a}}$ ed. 1819). 3 Tomos e outras prosas. (Sel. e pref.) João Palma-Ferreira. Lisboa: Estudios Cor, 1974.

Comboio de mentiras, vindo do reino petista com a fragata verdade encoberta por capitânia. Lisboa: Oficina de Simao Thaddeo Ferreira, 1801.

Barco da carreira dos tolos. Lisboa: Oficina de Simão Thaddeu Ferreira, 1803.

Espelho de jogadores para a correção dos que por este vício se perdem a si, seus bens e suas famílias. Intr. e notas de Fernanda Frazão. Lisboa: Apenas Livros, 2006a. 
Os enjeitados da fortuna expostos na roda do tempo. Obra moral e muito divertida. Lisboa: Impressão Régia, 1817.

. Os enjeitados da fortuna expostos na roda do tempo. Obra moral, e muito divertida. Com privilégio Real e Imperial. Lisboa: Impressão de João Nunes Esteves, 1826 (1 Folheto).

. Nova e pequena peça intitulada as desordens dos tafuis ou sete-é-ponto. Intr. e notas de Fernanda Frazão. Lisboa: Apenas Livros, 2006b.

Crítica à obra de José Daniel Rodrigues da Costa. In: Papeis Vários. Lisboa, 1800, p. 1-7.

Imprensa periódica portuguesa na metrópole e no império. Séculos XVII e XIX. Lisboa: Biblioteca Nacional, 1941.

CUNHA, A. Relances sobre os três séculos do jornalismo português: conferência proferida na Câmara Municipal de Lisboa, em 29 de novembro de 1941. Lisboa: [s/e], 1941.

FRAZÃO, F. “Introdução e notas”. In COSTA, J. D. R. da. Espelho de jogadores para a correção dos que por este vício se perdem a si, seus bens e suas famílias. Lisboa: Apenas Livros, 2006a.

LIMA, R. J. de. Biographia. In: O panorama: jornal litterário e instructivo da Sociedade Propagadora dos Conhecimentos Úteis, vol. IX, Lisboa, Imprensa da Sociedade Propagadora dos Conhecimentos Úteis, 1846.

MCKENZIE, D. F. Bibliography and the sociology of texts. In: Bibliography and the sociology of texts. Cambridge: Cambridge University Press, 2004.

MOREL, M. “Da gazeta tradicional aos jornais de opinião: metamorfoses da imprensa periódica no Brasil". In: NEVES, L. M. B. P. (org.) Livros e impressos: retratos do setecentos e do oitocentos. Rio de Janeiro: Editora da UERJ, 2009, p. 153 - 181.

NORONHA, J. F. de C. B. e. Manoel Maria Du Bocage. Excerptos seguidos de uma notícia sobre a sua vida e obras um juízo crítico, apreciações de belezas e defeitos e estudos de língua. Rio de Janeiro: Livraria Garnier, 1867.

Novo Almocreve das petas. Livro alegre e folgazão no gosto do antigo Almocreve das petas (sic) do célebre José Daniel Rodrigues da Costa. Lisboa: Tipografia Universal, 1874. 
PALMA-FERREIRA, J. "Seleção e Prefácio". In: O almocreve de petas, ou moral disfarçada para correção das miudezas da vida. Of. de Simão Tadeu Ferreira (2ª ed. 1819), Lisboa: Estudios Cor, 1974. SANTOS, M. J. M. O folheto de cordel: mulher, família e sociedade no Portugal do século XVIII (1750 -1800). Porto: 1987 (Dissertação de mestrado).

SILVA, A. M. da. Diccionario da língua portugueza. Lisboa: Typographia Lacerdina, 1813.

SILVA, Inocêncio Francisco da. Dicionário Bibliográfico Português. Lisboa: Imprensa Nacional, 1824.

SILVA, L. A. R. da. Memoria biografica e literaria acerca de Manoel Maria Barbosa du Bocage: do caracter das suas obras, e da influência que exerceu no gosto e nos progressos da poesia portugueza. Lisboa : Typ. da Academia, 1854.

TENGARRINHA, J. História da imprensa periódica portuguesa. Lisboa: Editorial Caminho, 1982. 


\section{Abstract \\ José Daniel Rodrigues da Costa and the Portuguese periodical humor press of the 18th century}

This article presents the results of our research on the Portuguese humor press of the 18th century. Taking as our object and topic the jesting works of the Portuguese writer José Daniel Rodrigues da Costa, we present the peculiarities of this written genre, using the concept of "editorial formula" by Roger Chartier (1997) and the conception of D. F. Mckenzie (2004) on the determination of the medium in the creation and retention of new literary genres. We analyze the inclusion of the author in the new regime of professionalization of the literary activity.

Keywords: José Daniel Rodrigues da Costa; Humor pamphlets; Portuguese press in the 18th century. 